\title{
O możliwości dziedziczenia opłaty dodatkowej za parkowanie w miejskiej strefie płatnego parkowania
}

\section{The possibility of inheriting an additional fee for parking in the urban paid parking zone}

Streszczenie. Ustawa o drogach publicznych wprowadza pewne instrumenty finansowe mające usprawnić możliwość korzystania z infrastruktury drogowej. Jednym z takich możliwości jest wprowadzenie strefy płatnego parkowania. Orzecznictwo i judykatura wypracowały zasady dotyczące poboru opłaty dodatkowej za parkowanie. W praktyce może powstać jednak sytuacja, że opłatę dodatkową powinna ponieść osoba zmarła. Powstaje zatem problem związany z sukcesją opłaty dodatkowej.

Słowa kluczowe: strefa płatnego parkowania; ustawa o drogach publicznych; opłata dodatkowa; zobowiązany; dziedziczenie.

Abstract. The Act on Public Roads introduces certain financial instruments to improve the use of a road infrastructure. One of such possibilities is an introduc- 
tion of a paid parking zone. Jurisprudence and judicature have developed rules regarding a collection of an additional fee for parking. In practice, however, a situation may arise that the additional fee should be borne by the deceased. Therefore, there is a problem related to the succession of the additional fee.

Keywords: paid parking zone; Act on public roads; additional payment; obliged; inheritance.

\section{Wstęp}

Ustawa o drogach publicznych ${ }^{1}$ wprowadza pewne instrumenty finansowe mające usprawnić możliwość korzystania z infrastruktury drogowej. Jednym z takich możliwości jest wprowadzenie strefy płatnego parkowania.

Ustawodawca wprost przewidział, że strefę płatnego parkowania ustala się na obszarach charakteryzujących się znacznym deficytem miejsc postojowych, jeżeli uzasadniają to potrzeby organizacji ruchu, w celu zwiększenia rotacji parkujących pojazdów samochodowych lub realizacji lokalnej polityki transportowej, w szczególności w celu ograniczenia dostępności tego obszaru dla pojazdów samochodowych lub wprowadzenia preferencji dla komunikacji zbiorowej (art. 13b ust. 2 u.d.p.).

Wyznaczenie strefy płatnego parkowania następuje w drodze aktu prawa miejscowego przez radę gminy (radę miasta), która podejmuje stosowną uchwałę $\mathrm{w}$ tym zakresie. W powyższym akcie rada gminy (rada miasta) obligatoryjne ustala wysokość opłaty za postój pojazdów samochodowych na drogach publicznych w strefie płatnego parkowania, z tym że opłata za pierwszą godzinę postoju pojazdu samochodowego nie może przekraczać 3 zł, a także określa sposób pobierania tej opłaty. Fakultatywnie istnieje możliwość wprowadzenia przepisów dotyczących opłat abonamentowych lub zryczałtowanych oraz zerową stawkę opłaty dla niektórych użytkowników drogi (art. 13b ust. 4 u.d.p.).

Ustawa z dnia 21 marca 1985 r. o drogach publicznych (tekst jedn. Dz.U. z 2016 r., poz. 1440, dalej: u.d.p.). 
Opłatę pobiera się za parkowanie pojazdów samochodowych w strefie płatnego parkowania, w wyznaczonym miejscu, w określone dni robocze, w określonych godzinach lub całodobowo (art. 13b ust. 1 u.d.p.).

W niniejszym opracowaniu zostanie podjęta próba omówienia sytuacji, w której nie została uiszczona opłata za parkowanie pojazdu w wyznaczonej strefie płatnego parkowania, a osoba, która była do tego zobowiązania, zmarła. Oznacza to, że zostanie postawiona próba udzielenia odpowiedzi, czy jest dziedziczny (przechodzi na następców prawnych) obowiązek uiszczenia tzw. opłaty dodatkowej. Uwagę skoncentruję na aspektach materialnych omawianego zagadnienia, a zostaną w nim pominięte aspekty proceduralne związane z poborem opłaty dodatkowej.

\section{Charakter prawny opłaty dodatkowej}

Opłata dodatkowa zgodnie z przepisem art. 13f u.d.p. jest opłatą pobieraną przez zarząd drogi, a w przypadku jego braku - zarządcę - w przypadku nieuiszczenia opłaty za parkowanie pojazdu samochodowego na drogach publicznych w strefie płatnego parkowania. Jej wysokość jest ustalana $\mathrm{w}$ drodze aktu prawa miejscowego wydawanego przez radę gminy (radę miasta), lecz nie może przekroczyć $50 \mathrm{zł}$.

Dopuszczalna jest także możliwość poboru takiej opłaty przez partnera prywatnego, jeżeli doszło do zawarcia umowy o partnerstwie publiczno-prywatnym (art. 13h u.d.p.).

W judykaturze przyjmuje się w odniesieniu do opłaty dodatkowej, że „Źródło powstania obowiązku podlegającego egzekucji wynikało bowiem bezpośrednio z przepisów prawa. Dla jego powstania, pod rządami obowiązujących przepisów, nie było potrzebne skonkretyzowanie tego obowiązku w drodze indywidualnego aktu administracyjnego"². Powyższy pogląd uzyskał także powszechną aprobatę w orzecznictwie ${ }^{3}$, a także literaturze ${ }^{4}$.

2 Wyrok NSA z dnia 7 grudnia 2005 r., FSK 2580/04, Centralna Baza Orzeczeń Sądów Administracyjnych (CBOSA).

3 Potwierdzeniem powyższego poglądu są liczne orzeczenia sądów administracyjnych dotyczących omawianej kwestii, np.: wyrok NSA z dnia 11 marca 2009 r., I OSK 
Opłata dodatkowa nie jest więc konkretyzowana w drodze aktu administracyjnego, co oznacza, że nie znajdują zastosowania do jej określenia ani przepisy Kodeksu postępowania administracyjnego ${ }^{5}$, ani ordynacji podatkowej $^{6}$.

W praktyce oznacza to, że jedyne środki prawne, które przysługują podmiotowi, od którego zarząd drogi domaga się uiszczenia opłaty (zobowiązanemu), znajdują się w przepisach ustawy o postępowaniu egzekucyjnym $\mathrm{w}$ administracji ${ }^{7}$. Jedynym środkiem prawnym zobowiązanego jest zatem zarzut złożony na podstawie przepisu art. 33 § 1 u.p.e.a.

Obecnie jest to kwestia, która nie wywołuje wątpliwości, gdyż przepis art. 40d ust. 2 u.d.p., wprost stanowi, że opłaty określone w art. $13 f$ ust. 1 u.d.p. podlegają przymusowemu ściągnięciu w trybie określonym w przepisach o postępowaniu egzekucyjnym w administracji.

Opłata dodatkowa nie jest karą za nieuiszczenie opłaty za parkowanie, lecz opłatą publiczną o charakterze dyscyplinującym za parkowanie (pozostawanie) pojazdu w strefie płatnego parkowania bez uiszczonej opłaty za parkowanie, a więc za takie - nieuprawnione korzystanie pojazdu z drogi publicznej ${ }^{8}$.

W literaturze wprost uznaje się, że „Opłata dodatkowa nie jest typową karą orzekaną w określonym postępowaniu, tak jak grzywna orzekana przez sąd lub w drodze mandatu karnego przez uprawnionego funkcjona-

1513/08, CBOSA, wyrok WSA o w Szczecinie z dnia 7 maja 2009 r., II SA/Sz 232/09, CBOSA, czy wyrok WSA w Poznaniu z dnia 29 września 2010 r., I SA/Po 459/10, CBOSA.

4 P. Zaborniak, Ustawa o drogach publicznych. Komentarz, [w:] Maciejko W., Zaborniak P., Ustawa o drogach publicznych. Komentarz, LexisNexis 2010, Komentarz do art. $13 f$ (eLex).

5 Ustawa z dnia 14 czerwca 1960 Kodeks postępowania administracyjnego (tekst jedn. Dz.U z 2017 r., poz. 1257, dalej: k.p.a.).

$6 \quad$ Ustawa z dnia 29 sierpnia 1997 r. Ordynacja podatkowa (tekst jedn. Dz.U. z 2017 r., poz. 201, dalej: o.p.); szerzej T. Brzezicki, W. Morawski, Zakres przedmiotowy Ordynacji podatkowej w świetle orzecznictwa sq̨dów administracyjnych, „Przegląd Orzecznictwa Podatkowego” 2009, nr 6, s. 525.

7 Ustawa z dnia z dnia 17 czerwca 1966 r. o postępowaniu egzekucyjnym w administracji (tekst jedn. Dz.U. z 2017 r., poz. 1201, dalej: u.p.e.a.).

8 Wyrok WSA w Szczecinie z dnia 5 listopada 2015 r., I SA/Sz 138/15, CBOSA, wyrok WSA w Szczecinie z dnia 23 lutego 2011 r., I SA/Sz 952/10, CBOSA, wyrok NSA z dnia 9 marca 2017 r., II GSK 1683/15, CBOSA. 
riusza publicznego czy kara pieniężna nakładana w drodze decyzji administracyjnej. Niemniej nie można odmówić opłacie dodatkowej, określonej w art. 13f u.d.p., sankcyjnego charakteru"9.

Konkludując, należy stwierdzić, że obowiązek uiszczenia opłaty za parkowanie pojazdu samochodowego w strefie płatnego parkowania jest obowiązkiem wynikającym z mocy samego prawa, tj. z przepisów u.d.p. i wydanej z jej upoważnienia uchwały rady miasta, stanowiącej - w myśl art. 87 ust. 2 Konstytucji Rzeczypospolitej Polskiej - akt prawa miejscowego obowiązujący każdego na obszarze działania organu, który je ustanowił.

\section{Podmiot zobowiązany do uiszczenia opłaty}

W świetle przedmiotu niniejszej analizy należy ustalić podmiot zobowiązany do uiszczenia opłaty. Przepis art. 13f u.d.p. nie wskazuje wprost podmiotu odpowiedzialnego (zobowiązanego) do uiszczenia opłaty. Należy jednak zauważyć, że obowiązek ponoszenia opłaty za korzystanie z dróg publicznych obciąża, co do zasady, korzystającego z takiej infrastruktury. Wynika to z faktu, że art. 13f u.d.p. powinien być interpretowany łącznie z przepisem art. 13 pkt 1 u.d.p., z którego wprost wynika, że to korzystający z dróg publicznych są obowiązani do ponoszenia opłat za postój pojazdów samochodowych na drogach publicznych w strefie płatnego parkowania.

W judykaturze i w praktyce przyjmuje się, że istnieje domniemanie, iż zobowiązanym do zapłaty opłaty dodatkowej jest właściciel (współwłaściciel) pojazdu. Może się on zwolnić od odpowiedzialności, wskazując osobę, która pojazd zaparkowała bez uiszczenia wymaganej opłaty ${ }^{10}$. Powyższy pogląd rozciąga się także na sytuacje, w której właścicielem pojazdu jest osoba prawna ${ }^{11}$ lub pojazd znajduje się we współwłasności ${ }^{12}$.

9 R. Strachowska, Ustawa o drogach publicznych. Komentarz, ABC 2012, Komentarz do art. $13 f$ (eLex).

10 Wyrok WSA w Krakowie z dnia 6 lipca 2016 r., I SA/Kr 271/16, CBOSA.

11 Wyrok WSA w Szczecinie z dnia 5 listopada 2015 r., I SA/Sz 138/15, LEX nr 1935857. 
WSA w Krakowie wskazuje, że „Użyte przez ustawodawcę pojęcie «korzystający» obejmuje, poza właścicielem pojazdu, również inne osoby, tj. osoby korzystające z pojazdu na podstawie tytułu prawnego, za zgodą właściciela, jak i osoby działające bez takiego tytułu czy zgody. Skoro korzystającym z pojazdu samochodowego, a tym samym z drogi publicznej, jest z reguły jego właściciel (współwłaściciel), to w razie stwierdzenia braku wniesienia opłaty parkingowej, we właścicielu pojazdu należy upatrywać zobowiązanego do uiszczenia opłaty dodatkowej, chyba że ten wykaże, iż wyzbył się władztwa fizycznego nad pojazdem na rzecz innej osoby, czy to na skutek własnego oświadczenia woli, czy wbrew własnej woli” ${ }^{13}$.

Zaznaczyć należy, że domniemanie obciążenia zobowiązaniem za opłatę dodatkową właściciela pojazdu jest domniemaniem o charakterze faktycznym. Zwraca na to uwagę WSA w Krakowie, stwierdzając, że „Do przyjęcia takiego domniemania uprawniają zasady doświadczenia życiowego i logicznego rozumowania. Jeśli ktoś jest właścicielem samochodu, to przede wszystkim on z niego korzysta. Drugim elementem ww. domniemania jest zaś założenie, że jeśli właściciel samochodu z niego w danym dniu nie korzystał, to wie, kto to czynił i może udowodnić, że swój pojazd użyczył innej osobie"14. Podnosi się także, że do takiego poglądu uprawnia także „wynikająca z prawa własności tzw. triada uprawnień właścicielskich, czyli prawo do: posiadania (ius possidendi), korzystania i rozporządzania (ius disponendi)" ${ }^{\text {15 }}$. W tym zakresie zauważa się, że „Dodatkowo, w przypadku gdy wszczęte postępowanie egzekucyjne wobec jednego z współwłaścicieli nie może się toczyć (np. z powodu jego śmierci), wierzyciel może wskazać drugiego, chyba że na poprzednim etapie ustalono ponad wszelką wątpliwość, że to zmarły współwłaściciel korzystał z płatnej strefy parkowania. Oczywistym jest też, że jeżeli dotychczas wierzyciel i organ egzekucyjny nie wyjaśniali tej kwestii, wskazany

\footnotetext{
Wyrok WSA w Poznaniu z dnia 30 maja 2017 r., III SA/Po 1273/16, LEX nr 2305055. Wyrok WSA w Krakowie z dnia 6 lipca 2016 r., I SA/Kr 271/16, CBOSA. Wyrok WSA w Krakowie z dnia 20 listopada 2013 r., I SA/Kr 1582/13, CBOSA. Wyrok NSA z dnia 9 marca 2017 r., II GSK 1683/15, CBOSA.
} 
w drugiej kolejności następny z współwłaścicieli może uwolnić się od odpowiedzialności, wykazując, kto faktycznie korzystał z samochodu”16.

Należy stwierdzić, że opłata dodatkowa, na zasadzie domniemania faktycznego, obciąża właściciela pojazdu, chyba że ten wskaże podmiot (użytkownika pojazdu), który faktycznie zaparkował w strefie płatnego parkowania. Powyższe ustalenie, jak już wcześniej wspomniano, powinno nastąpić na etapie postępowania egzekucyjnego. Takie stanowisko ułatwia właściwemu podmiotowi pobór opłaty, gdyż zwalnia w większości sytuacji z obowiązku prowadzenia żmudnego postępowania wyjaśniającego zmierzającego do ustalenia, kto faktycznie kierował pojazdem.

Rzeczywiste ustalenie podmiotu zobowiązanego następuje dopiero na etapie postępowania egzekucyjnego w chwili, gdy zobowiązany wniesie zarzut wszczęcia egzekucji w stosunku do niewłaściwego podmiotu, wskazując jako podstawę błąd co do osoby zobowiązanego (art. 33 § 1 pkt 4 u.p.e.a.). W takiej sytuacji to „Organ egzekucyjny jest zobowiązany po wniesieniu zarzutu do przeprowadzenia postępowania wyjaśniającego, przy zastosowaniu przepisów k.p.a. W sytuacji bowiem, kiedy obowiązek powstaje z mocy prawa, jest to jedyna możliwość obrony swoich praw przez dłużnika”17.

Powyższe wywody prowadzą do wniosku, że opłata dodatkowa zawsze obciąża konkretny podmiot, którym w zależności od ustaleń będzie kierowca, który zaparkował pojazd w strefie płatnego parkowania lub właściciel pojazdu (w sytuacji, gdy nie jest w stanie uwolnić się o odpowiedzialności poprzez wskazanie osoby zobowiązanej).

Powstaje zatem praktyczne pytanie, czy opłatę dodatkową można pobrać w sytuacji, gdy zmarła osoba zobowiązana do jej uiszczenia. Powyższe sprowadza się do ustalenia, czy następuje sukcesja opłaty dodatkowej.

Wyrok WSA w Krakowie z dnia 20 listopada 2013 r., I SA/Kr 1582/13, CBOSA.

WSA w Gdańsku w wyroku z dnia 26 kwietnia 2012 r., III SA/Gd 107/12, CBOSA, także wyrok WSA w Krakowie z dnia 22 sierpnia 2012 r., III SA/Kr 686/11, CBOSA, wyrok WSA w Gdańsku z dnia 26 kwietnia 2012 r., III SA/Gd 107/12, CBOSA, wyrok WSA w Białymstoku z dnia 21 grudnia 2010 r., II SA/Bk 712/10, CBOSA. 


\section{Prawna możliwość dziedziczenia opłaty dodatkowej}

Bezspornym jest, że opłata dodatkowa nie posiada cywilnego charakteru. Nie jest wiec możliwym uznanie, że powyższy obowiązek ulega dziedziczeniu na podstawie zasad zawartych w Kodeksie cywilnym ${ }^{18}$. Zauważyć bowiem należy, że zgodnie z przepisem art. 922 § 1 k.c. prawa i obowiązki majątkowe zmarłego przechodzą z chwilą jego śmierci na jedną lub kilka osób stosownie do przepisów księgi niniejszej. Ponadto nie należą do spadku prawa i obowiązki zmarłego ściśle związane z jego osobą, jak również prawa, które z chwilą jego śmierci przechodzą na oznaczone osoby niezależnie od tego, czy są one spadkobiercami (art. 922 § 2 k.c.).

Mając na względzie publicznoprawny charakter opłaty dodatkowej, należy rozważyć możliwość następstwa prawnego w świetle przepisów prawa publicznego. W rozważanej sytuacji znajduje zastosowanie przepis art. 97 o.p. w związku z przepisem art. 60 ust. 7 ustawy o finansach publicznych, który nakazuje uznanie opłaty za należności budżetowe o charakterze publicznoprawnym, gdyż jest to dochód pobierany przez samorządowe jednostki budżetowe na podstawie odrębnych ustaw.

W odniesieniu do poboru opłat należy stosować Kodeks postępowania administracyjnego (co nie ma istotnego znaczenia na tle rozpatrywanych zagadnień) oraz odpowiednio przepisy działu III Ordynacji podatkowej, a więc także przepisy o następstwie prawnym.

Zgodnie z przepisem art. 97 § 1 o.p. spadkobiercy podatnika, z zastrzeżeniem $\S 2$, przejmują przewidziane w przepisach prawa podatkowego majątkowe prawa i obowiązki spadkodawcy. Powstaje jest pytanie, czy w zaistniałej sytuacji powstał na osobie zobowiązanej (osobie zmarłej) do uiszczenia opłaty obowiązek i zobowiązanie podatkowe.

Zgodnie z przepisem art. 4 o.p. obowiązkiem podatkowym jest wynikająca z ustaw podatkowych nieskonkretyzowana powinność przymusowego świadczenia pieniężnego w związku z zaistnieniem zdarzenia określonego w tych ustawach. Natomiast zobowiązaniem podatkowym jest wynikające z obowiązku podatkowego zobowiązanie podatnika do zapłacenia na rzecz Skarbu Państwa, województwa, powiatu albo gminy podat-

18 Ustawa z dnia 23 kwietnia 1964 r. (tekst jedn. Dz.U. z 2017 r., poz. 459 ze zm., dalej: k.c.). 
ku w wysokości, w terminie oraz w miejscu określonych w przepisach prawa podatkowego (art. 5 o.p.).

Niewątpliwie w zaistniałej sytuacji istnieje obowiązek podatkowy, natomiast trudno jest uznać, że przed wszczęciem egzekucji administracyjnej powstało zobowiązanie podatkowe. Wynika to z faktu, że opłata dodatkowa nie jest konkretyzowana poprzez wydanie aktu administracyjnego lub przez inne zdarzenie (np. złożenie deklaracji) przez osobę zobowiązaną do uiszczenia opłaty z uwagi na fakt, że ta ostania wynika bezpośrednio z przepisów prawa. W powyższym zakresie należy zauważyć, że przepis nie wskazuje wprost podmiotu odpowiedzialnego za uiszczenie opłaty. Dopiero praktyka (judykatura) przyjmuje, że taki obowiązek ciąży na kierującym pojazdem lub właścicielu pojazdu. Oznacza, że co do zasady podmiotem odpowiedzialnym za uiszczenie opłaty jest podmiot władający pojazdem w dniu, w którym powstał obowiązek uiszczenia opłaty, lecz niekoniecznie właściciel. Nie jest to więc opłata związana z pojazdem, lecz pewnym zdarzeniem połączonym z działaniem podmiotu dysponującego pojazdem.

W powyższym zakresie nie istnieje więc prawna możliwość obciążenia takim zobowiązaniem spadkobierców właściciela pojazdu. Właściciel pojazdu nie jest bowiem każdorazowo zobowiązany do uiszczenia takiej opłaty, zaś taka opłata przed wszczęciem egzekucji nie została skonkretyzowana podmiotowo.

Za indywidualnym (osobistym) charakterem takiej opłaty przemawia także sankcyjny charakter opłaty, jej celem jest bowiem dążenie do sytuacji, w której podmiot zobowiązany uiszcza ją w trybie zwykłym przewidzianym w uchwale rady gminy (rady miasta).

Konkludując, należy stwierdzić, że sam fakt ustalenia że istnieje obowiązek uiszczenia opłaty dodatkowej nie oznacza, że został skonkretyzowany podmiot zobowiązany do jej uiszczenia.

Możliwość dziedziczenia obowiązków o charakterze publicznoprawnych jest możliwa tylko w przypadku skonkretyzowania podmiotowego i przedmiotowego takiej opłaty.

W literaturze przyjmuje się, że „zgodnie z zasadą sukcesji uniwersalnej - z chwilą śmierci osoby, która otrzymała nowe nieruchomości wy- 
dzielone w wyniku scalenia i podziału, a nie została obciążona tego rodzaju daniną publiczną, obowiązek w postaci wniesienia opłaty adiacenckiej przechodzi na jej spadkobierców. Skoro nie jest to obowiązek o charakterze cywilnoprawnym, to nie przechodzi na spadkobierców w drodze spadkobrania na zasadach ogólnych"19.

Za takim poglądem opowiada się także judykatura, stwierdzając, że „Obowiązek spadkodawcy w rozumieniu art. 97 § 1 o.p. w odniesieniu do opłaty planistycznej występuje tylko w sytuacji, gdy opłata ta została ustalona przed otwarciem spadku. Dopiero skonkretyzowana w ostatecznej decyzji administracyjnej opłata planistyczna może być uznana za odpowiednik zobowiązania podatkowego i co za tym idzie dopiero w przypadku wydania w stosunku do zbywcy nieruchomości takiej decyzji i uzyskania przez nią za jego życia przymiotu ostateczności, do wynikającego z tej decyzji zobowiązania do zapłaty renty planistycznej w określonej wysokości zastosowanie znaleźć mogą odpowiednio przepisy Ordynacji podatkowej, w tym szczególnie art. 98 § 1 tej ustawy.”20

Przedstawione poglądy dotyczą nieruchomości, jednak pokazują pewną zasadę związaną z sukcesją opłat administracyjnych. Uogólniając powyższe stanowisko, można je także zastosować w odniesieniu do opłaty dodatkowej.

Powyższe opłaty dotyczą danin pieniężnych związanych z nieruchomościami, natomiast zachodzi w tym zakresie podobieństwo, że w odniesieniu do zarówno wskazanych opłat, jak i opłaty dodatkowej danina jest związana z określoną rzeczą (nieruchomość - pojazd).

Podmiotowe skonkretyzowanie opłaty następuje dopiero poprzez skierowanie tytułu wykonawczego do indywidualnie oznaczonego podmiotu i ewentualnie dopiero na tym etapie, tj. w sytuacji już wszczętej egzekucji, istniałaby możliwość dokonania następstwa prawnego.

Uznanie innej możliwości oznaczałoby konieczność wydania decyzji o zakresie odpowiedzialności lub uprawnień poszczególnych spadkobier-

19 A. Lorek, Dziedziczenie obowiq̨zku pieniężnego w postaci opłaty adiacenckiej z tytułu scalenia i podziału nieruchomości jako obowiq̨zu pieniężnego o charakterze publicznoprawnym, „Nowe Zeszyty Samorządowe” 2016, nr 5, poz. 75, s. 27. 
ców na podstawie decyzji ostatecznych wydanych wobec spadkodawcy oraz jego zobowiązań wynikających z prawidłowych deklaracji (art. $100 \S 1$ o.p.), zaś w przypadku opłaty dodatkowej nie została wydana decyzja lub złożona deklaracja, gdyż wynika ona bezpośrednio z przepisów prawa.

\section{Podsumowanie}

W świetle przedstawionych argumentów opłata dodatkowa nie podlega dziedziczeniu na podstawie przepisów prawa cywilnego, co jest okolicznością bezsporną, a także nie ma podstaw prawnych na obciążenie powyższą opłatą spadkobierców kierowcy lub właściciela pojazdu.

W sytuacji, gdy zostało wszczęte postępowanie egzekucyjne, zaś osoba zmarła, jego następca prawny może skutecznie uwolnić się od odpowiedzialności, wskazując zmarłego jako osobę zobowiązaną. Nie ma podstaw do wszczęcia egzekucji administracyjnej w sytuacji, gdy przed wszczęciem postępowania egzekucyjnego ustalono, że korzystającym z dróg publicznych była osoba zmarła.

Następcy prawni bowiem zawsze mogliby zwolnić się od odpowiedzialności, wnosząc zarzut w postępowaniu egzekucyjnym i wskazując jako podstawę błąd co do osoby zobowiązanego (art. 34 § 1 pkt 4 u.p.e.a.) lub żądając umorzenia postępowania (art. 59 § 1 pkt 4 u.p.a.).

\section{Bibliografia:}

Brzezicki T., Morawski W., Zakres przedmiotowy Ordynacji podatkowej w świetle orzecznictwa sq̨ów administracyjnych, „Przegląd Orzecznictwa Podatkowego" 2009, nr 6, s. 513-528.

Lorek A., Dziedziczenie obowiq̨zku pieniężnego w postaci opłaty adiacenckiej z tytułu scalenia i podziału nieruchomości jako obowiq̨zk pieniężnego o charakterze publicznoprawnym, „Nowe Zeszyty Samorządowe” 2016, nr 5, s. 24-31.

Strachowska R., Ustawa o drogach publicznych. Komentarz, ABC 2012.

Maciejko W., Zaborniak P., Ustawa o drogach publicznych. Komentarz, LexisNexis 2010. 